\title{
Plantations of Cinnamomum camphora (Linn) Presl with Distinct Soil Bacterial Communities Mitigate Soil Acidity within Polluted Locations in Southwest China
}

\author{
Zhan Chen ${ }^{1, *(\mathbb{D})}$, Mia R. Maltz ${ }^{2,3}\left(\mathbb{D}\right.$, Yuguang Zhang ${ }^{1}\left(\mathbb{D}\right.$, Brendan J. $\mathrm{O}^{\prime}$ Brien $^{2,4}$, Monica Neff ${ }^{2,3}$, Yihao Wang ${ }^{5}$ and \\ Jixin Cao ${ }^{1}$
}

1 Key Laboratory of Forest Ecology and Environment of National Forestry and Grassland Administration, Research Institute of Forest Ecology, Environment and Protection, Chinese Academy of Forestry, Beijing 100091, China; yugzhang@sina.com.cn (Y.Z.); caojix@163.com (J.C.)

2 CoRenewal Incorporated, Irvine, CA 92614, USA; maltz@ucr.edu (M.R.M.); hyphaeconsulting@gmail.com (B.J.O.); mneff2000@gmail.com (M.N.)

3 Division of Biomedical Sciences, University of California, Riverside, CA 92521, USA

4 Hyphae Consulting, Inc., Burlington, VT 05401, USA

5 College of Geography and Tourism, Chongqing Normal University, Chongqing 401331, China; wyih515@163.com

* Correspondence: chenzhan0508@caf.ac.cn; Tel.: +86-10-62889540

\section{check for} updates

Citation: Chen, Z.; Maltz, M.R.; Zhang, Y.; O'Brien, B.J.; Neff, M.; Wang, Y.; Cao, J. Plantations of Cinnamomum camphora (Linn) Presl with Distinct Soil Bacterial Communities Mitigate Soil Acidity within Polluted Locations in Southwest China. Forests 2021, 12, 657 . https://doi.org/10.3390/f12060657

Academic Editors: Gerrit Angst and Eva Kaštovská

Received: 19 April 2021

Accepted: 19 May 2021

Published: 22 May 2021

Publisher's Note: MDPI stays neutral with regard to jurisdictional claims in published maps and institutional affiliations.

Copyright: (c) 2021 by the authors. Licensee MDPI, Basel, Switzerland. This article is an open access article distributed under the terms and conditions of the Creative Commons Attribution (CC BY) license (https:// creativecommons.org/licenses/by/ $4.0 /)$.
Abstract: Although the underlying mechanisms remain unknown, soils from different forest types exhibit distinct acidification-buffering capacities. We investigated soil properties and bacterial communities across five plantation types and different soil horizons in a severely acid-polluted site in Southwest China and evaluated the potential mechanisms driving differences in community structure. Soils collected from pure stands of Pinus massoniana Lamb.or Schima superba Gardn. et Champ. or mixed stands of these species showed the lowest soil $\mathrm{pH}$ and greater abundances of acid-producing and acidophilic taxa (Halanaerobiales and Rhodospirillales). Soils from pure stands of Cinnamomum camphora (Linn) Presl, or a mixture of C. camphora and P. massoniana, yielded the greatest concentrations of exchangeable calcium $(\mathrm{Ca})$ and magnesium $(\mathrm{Mg})$ and greater soil $\mathrm{pH}$. Increased relative abundances of beneficial taxa may have contributed to soil aggregate formation (e.g., Bradyrhizobium canariense and Terracidiphilus sp.) and heightened environmental stress resistance (e.g., Gaiellales). Fewer acid-producing and acidophilic taxa found in soils associated with C. camphora suggest that planting C. camphora may help soils recover from acidification, while planting S. superba may not be as beneficial. Our findings illustrate how differences in soil microbial communities may impact soil-acidification-buffering capacity across different forest types, which have important implications for understanding environmental functions within the context of microbial diversity.

Keywords: Cinnamomum camphora; Pinus massoniana; Schima superba; soil acidification; soil bacterial community; soil-buffering capacity

\section{Introduction}

Acid deposition is a global environmental issue that has attracted widespread attention for its adverse effects on ecosystems and natural resources [1,2]. Although some environmental occurrences exist, acid deposition is largely attributed to industrial pollution from the burning of fossil fuels, which release sulfur dioxide $\left(\mathrm{SO}_{4}{ }^{2-}\right)$ and nitrogen oxides $\left(\mathrm{NO}_{\mathrm{x}}\right)$ into the atmosphere, where they react with water, oxygen, and other chemicals to form acidic residues before falling to Earth. Despite governmental efforts to curb emissions linked to acid deposition [3,4] beginning in the 1980s, current rates in Southern China remain severe [2]. Industrial inputs of sulfur $(\mathrm{S})$ and nitrogen $(\mathrm{N})$ to ecosystems increase acid deposition and result in landscape degradation and biodiversity loss [5,6]. While the average rate of $\mathrm{SO}_{4}{ }^{2-}$ deposition showed a decline between the 1990s and the 2010s in 
China, the average rate of $\mathrm{NO}_{3}{ }^{-}$deposition increased, leading to greater acid deposition and subsequent acidification of soils during this period [2].

Soil acidification - as a result of acid deposition-is a formidable environmental issue [7-9], with negative impacts on both ecosystems and agriculture. Despite measurable reductions in new inputs $[1,10,11]$, some studies have shown that the recovery of acidified soils_-toward more neutral conditions—could be substantially delayed by historic stores of $\mathrm{SO}_{4}{ }^{2-}$ adsorbed to soils [1]. Soil nitrogen deposits have also been shown to exacerbate soil acidification and have therefore garnered widespread concern $[1,12,13]$. A global metaanalysis of 106 studies showed that soil pH not only decreases linearly with increasing rates of $\mathrm{N}$ deposition, but also that $\mathrm{N}$ deposition reduces soil $\mathrm{pH}$ by approximately 0.26 [14]. A review of inorganic $\mathrm{N}$ deposition in 69 forest ecosystems at 50 different sites throughout China demonstrated $\mathrm{N}$ deposition, via precipitation, ranging from 2.6 to $48.2 \mathrm{~kg} \mathrm{ha}^{-1}$ $\mathrm{y}^{-1}$ [13]. Additionally, these studies showed that an average of $16.6 \mathrm{~kg} \mathrm{ha}^{-1} \mathrm{y}^{-1}$ ammonium $\left(\mathrm{NH}_{4}{ }^{+}\right)$accounted for approximately $63 \%$ of total inorganic $\mathrm{N}$ deposition [13]. $\mathrm{NH}_{4}{ }^{+}$ions deposited in soils can displace base cations and reduce their ability to buffer against acidification. Furthermore, $\mathrm{H}^{+}$ions released into soil when $\mathrm{NH}_{4}{ }^{+}$is absorbed by plant roots can further exacerbate this acidification effect $[14,15]$. Further research is needed to elucidate the belowground mechanisms that force acidified soils toward more neutral conditions amidst continued wet $\mathrm{N}$ deposition and the release of historic soil $\mathrm{N}$ stores.

Because different tree species affect the cation exchange capacity and cation binding properties of organic matter differently [16], manipulative treatments within a range of different forest types are important for assessing corresponding changes to soil $\mathrm{pH}$ levels [17]. For example, previous studies have shown that litter removal may have opposing effects on differing tree stands. Specifically, in Pinus sp. stands, litter removal resulted in increased soil $\mathrm{pH}$ levels $[18,19]$, whereas litter removal within mixed pinea and deciduous forests showed the opposite effect and instead decreased within soils initially characterized within a range of $\mathrm{pH} 5$ to $\mathrm{pH} 5.5$ [20]. Therefore, both tree-planting strategies and forest management approaches could differentially affect soil properties in ecosystems suffering from the long-term effects of acidic deposition.

In general, coniferous forests have weaker soil-buffering capacities than mixed or broadleaf forests. This is likely due to the greater release of $\mathrm{H}^{+}$ions into soils within coniferous forests, which may balance the high uptake of exchangeable cations relative to anions [21]. The influence of tree species on soil acidity has also been shown to be related to litter quality [22-24]. For example, tree species with Ca-enriched litter corresponded to lower soil acidity $[22,24]$. Some broadleaf species, including C. camphora, have been shown to have higher levels of $\mathrm{Ca}$ in their litter compared to Pinus massoniana Lamb. [25]. Tree species that produce leachate with relatively high levels of dissolved organic carbon (DOC) were related to soil $\mathrm{pH}$, which indicated that greater quantities of DOC accompanied soils characterized by lower $\mathrm{pH}$ [26]. In other words, increasing $\mathrm{C}$ deposition to the forest floor may result in lower $\mathrm{pH}$ levels. Coniferous species are generally associated with higher DOC fluxes in forest floor leachate than broadleaf species [27-29], which suggests an affinity for more acidic conditions. Previous research has shown that litter of the native broadleaf species, $S$. superba, has greater buffering capacity against acidification than that of P. massoniana, likely due to greater amounts of base cations present in S. superba litter [30]. In contrast to this finding, Li et al. [31] demonstrated that plantations of S. superba actually exacerbated soil acidification, which may have resulted from increased absorption of base cations and leaching of $\mathrm{H}^{+}$ions from rapid and excessive growth within these severely acidified soils ( $\mathrm{pH}$ approximately 3.61). Given the conflicting evidence as to the effect of S. superba litter inputs on soil acidity, a more detailed characterization of $S$. superba litter quality, coupled with an investigation of the belowground mechanisms driving indirect and direct effects on soil acidification, could help clarify this scientific phenomenon.

While some studies have reported the effects of soil acidification on soil microbial communities, few have included comparisons among sites along a pollution gradient. Through simulated acid rain treatments in field, greenhouse, or laboratory environments, 
previous authors have analyzed a variety of different ecosystem functions within a single site $[9,32-34]$ and determined that increased soil acidification reduced bacterial diversity in soils within a $\mathrm{pH}$ range of four to seven. This observation may result from both ecological and evolutionary mechanisms regulating soil bacterial communities [33]. Simulated acid rain experiments provided evidence that soil microbial biomass, community diversity, and microbial metabolic functions are all decreased from exposure to acidic inputs [32,35] and that both soil bacterial and fungal community composition and structure can shift with exposure to more acidic conditions $[9,36]$. However, little is known about how different soil bacterial communities associated with different forest types may affect soil-buffering capacity given similar degrees of acidic deposition and exposure.

In China, some of the most severe levels of acid deposition have been recorded in the Southwest region near Tieshanping, making it an important study site for determining the long-term effects of acid deposition in soils. Pure stands of P. massoniana (Pi) were planted in 1962 following the clear-cutting of a natural pine forests. Long-term exposure to acid rain has resulted in declining growth for these plantings and general forest dieback. Other native tree species, including C. camphora (Ci) and S. superba (Sc), were planted between the 1980s and 1990s, in an effort to improve forest health and increase biodiversity. Pure stands of $\mathrm{Ci}$ and $\mathrm{Sc}$ were established along with mixed plantings of $\mathrm{Pi}$ and $\mathrm{Ci}$ ( $\mathrm{Ci}$ _Pi) and $\mathrm{Pi}$ and $\mathrm{Sc}\left(\mathrm{Sc} \_\mathrm{Pi}\right)$ to test the effects of implementing different planting treatments to reduce soil acidification.

Beginning in 2000, Tieshanping was one of five monitored sites used in the ChineseNorwegian cooperative Integrated Monitoring Program on Acidification of Chinese Terrestrial Systems [37]. This project included multiple studies on plantations of P. massoniana, including forest health assessments, $\mathrm{N}$ deposition status, effects of liming on forest health, forest hydrology, soil quality, and litter decomposition dynamics [1,12,38,39]. However, even after thirty years since the initial treatment plantings, it remains unclear as to whether these treatments were helpful in reducing soil acidity toward more favorable neutral conditions.

Likewise, soil bacterial communities present within acidic soils remain relatively uncharacterized. Moreover, little is known about how soil bacterial communities influence soil acidity between different forest types. Bacteria are the most abundant and diverse group of soil organisms [40]. Highly diverse bacterial communities may improve soil quality and help plants adapt to acidic soil environments. Although soil bacterial communities may respond to soil acidification, the relationship between soil bacterial community structure and soil quality within different forest types remains poorly understood. In this study, we compared the physicochemical properties and bacterial community structure of soils from pure stands of $\mathrm{Ci}$, Pi and Sc and mixed stands of Ci_Pi and Sc_Pi in Tieshanping, China, to examine the following: (1) How does soil quality differ among forest types after decades of acid deposition? (2) What differences are detectable for soil bacterial communities among these various forest types? (3) Do the patterns illustrated for bacterial communities relate to soil acidity indicators?

\section{Materials and Methods}

\subsection{Site Description and Plot Design}

In June of 2018, four $20 \mathrm{~m} \times 20 \mathrm{~m}$ square study plots were established in each of the five different forest stand combinations found within the heavily polluted "acid rain control zone" in Tieshanping Forest Park (106 $41.24^{\prime}$ E, $\left.29^{\circ} 37.42^{\prime} \mathrm{N}\right)$, located approximately $25 \mathrm{~km}$ northwest of Chongqing in subtropical Southeast China [41]. Soils are classified as Haplic Acrisol in FAO [42]. Dominant ground cover vegetation within these stands includes Camellia oleifera, Randia cochinchinensis, and Loropetalum chinense. Other less common understory species include Dicranopteris pedata, Woodwardia japonica, Dryopteris fuscipes, Miscanthus sinensis, and Oplismenus undulatifolius. 


\subsection{Soil Samplings and Analysis}

Soil samples were collected from the $\mathrm{O}$ horizon and $\mathrm{A}$ horizon at 10 random points by digging soil profiles within each plot. Ten subsamples from each horizon were collected integrally over the whole horizon and mixed to create a single composite sample for each horizon. Composite samples were subdivided into two separate aliquots and stored at $-80{ }^{\circ} \mathrm{C}$ until subsequent analyses were performed. One aliquot was used for the determination of soil physicochemical properties, and the second was reserved for molecular analysis of soil bacterial community composition and structure.

Soil $\mathrm{pH}$ was measured (pH probe Delta 320, Mettler-Toledo, Shanghai, China) within a soil slurry mixture at a 1:5 ratio of air-dried soil to distilled water (wt:vol). Soil organic matter was determined via potassium dichromate oxidation titration. $\mathrm{NO}_{3}-\mathrm{N}$ and $\mathrm{NH}_{4}-\mathrm{N}$ were extracted from fresh soils with $0.01 \mathrm{~mol} \cdot \mathrm{L}^{-1} \mathrm{CaCl}_{2}$, and the extracts were subsequently read through a Seal AA3 flow analyzer (Germany). Soil total phosphorus (P) and potassium (K) were extracted with $\mathrm{NaOH}$ and then analyzed by the Mo-Sb colorimetric method and flame photometric method, respectively. Exchangeable $\mathrm{Ca}$ and $\mathrm{Mg}$ was determined by ICP (iCAP 7200 ICP-OES, Thermo Scientific Inc., Waltham, MA USA). Soil microbial biomass carbon (SMBC) and nitrogen (SMBN) were determined using standard fumigationextraction methods [43].

Soil bacterial community composition was characterized via high-throughput sequencing. DNA was extracted from soil aliquots by targeting hypervariable portions of the V3-V4 region of the 16S rRNA gene for amplification by polymerase chain reaction (PCR). PCR products were purified and quantified prior to pooling in equimolar concentrations for Illumina Miseq sequencing (Illumina Incorporated, California; SI Molecular Methods; details of DNA extraction and bioinformatic analyses described within the Supplemental Information).

\subsection{Statistical Analysis}

Treatment means were statistically compared using the statistical package SPSS (SPSS Inc., Chicago, IL, USA). Pairwise post hoc tests of one-way ANOVA and Tukey's HSD were performed to determine significant differences across all soil properties, bacterial diversities, and relative taxa abundances among different forest types within each soil horizon. For each forest type, independent sample t-tests were performed to detect significant differences across soil properties, between $\mathrm{O}$ horizons and A horizons.

Differences in bacterial community composition and structure were determined by comparing the average relative abundance of each operational taxonomic units (OTU) detected within each sample. Bray-Curtis distance matrices were constructed to compare dissimilarities and compositions among soil bacterial communities across different forest types and horizon layers; these distance matrices were also used to examine the relationship between the relative abundance of highly abundant genera and environmental variables. Principal coordinates analysis (PCoA) plots were used to visualize shifts in community composition and evaluated with both redundancy analysis (RDA) and PERMANOVA analysis, using Bray-Curtis dissimilarities with the Adonis function in the vegan package of $\mathrm{R}[44,45]$. Before RDA analysis, environmental factors were screened with variance inflation factor (VIF) analysis, such that $p>0.05$ or VIF $>10$ were removed from further analyses; hence, $\mathrm{TN}, \mathrm{NH}_{4}-\mathrm{N}, \mathrm{Ca}$, and $\mathrm{Mg}$ were removed from downstream analyses. We used the $\mathrm{R}$ software vegan package to generate heat map visualizations that depicted the relative abundances for the fifty most abundant genera. To further elucidate specific bacteria that may be important for determining soil bacterial community structure among forest types, we used a one-way ANOVA and Tukey's HSD to detect differences in bacterial genera. Bacterial community diversity was estimated using both the Shannon and Chao indices. To investigate the main effects driving soil bacterial community structure, we used Spearman's rank correlations to calculate differences between soil properties, as well as to depict the relative abundances of highly significant genera among different forest types. 


\section{Results}

\subsection{Soil Physicochemical Properties and Soil Microbial Biomass}

In the $\mathrm{O}$ horizon, pure stands of $\mathrm{Ci}$ showed the highest soil $\mathrm{pH}$ value $(\mathrm{pH}=4.6)$, followed by mixed stands of $\mathrm{Ci} \_\mathrm{Pi}(\mathrm{pH}=4.54)$. Mixed stands of Sc_Pi showed the lowest soil $\mathrm{pH}(\mathrm{pH}=3.80)$. For the A horizon, we found that mixed stands of $\mathrm{Ci}-\mathrm{Pi}$ and $\mathrm{Ci}$ had the highest soil $\mathrm{pH}(\mathrm{pH}=4.40$ and $\mathrm{pH}=4.39$, respectively). Overall, soil $\mathrm{pH}$ values were significantly greater in the A horizon than the O_horizon in Pi, Sc, and Sc_Pi $(p<0.001)$, while in both $\mathrm{Ci}$ and $\mathrm{Ci}$ _Pi forests, the $\mathrm{A}$ horizon showed lower soil $\mathrm{pH}$ values than were measured within the $\mathrm{O}$ horizon $(p<0.001)$. The highest values of exchangeable $\mathrm{Ca}$ and $\mathrm{Mg}$ were measured in the $\mathrm{O}$ horizon of $\mathrm{Ci}$ _Pi stands; the A horizon from beneath Ci_Pi stands was characterized by the highest values of exchangeable $\mathrm{Ca}$ and $\mathrm{Mg}$ (Figure 1).
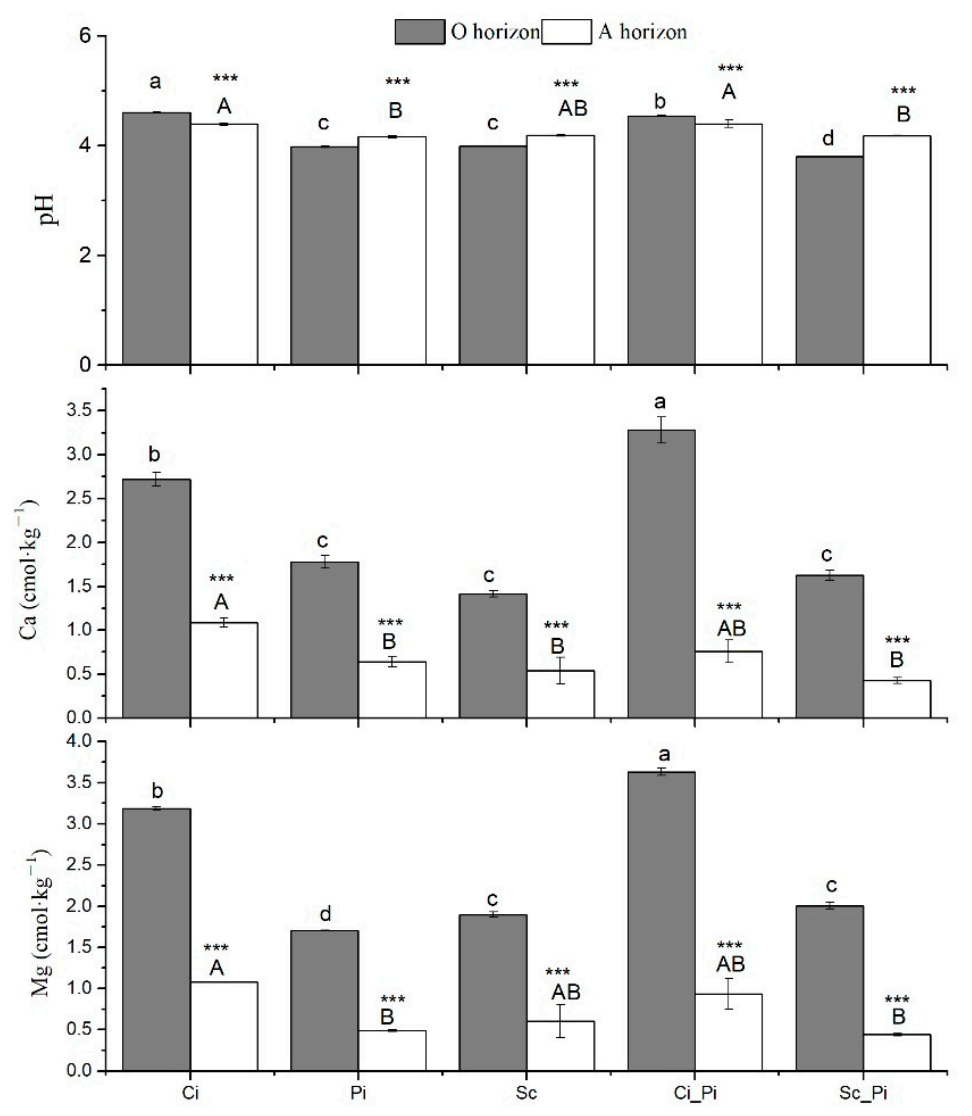

Figure 1. Soil $\mathrm{pH}$ and exchangeable $\mathrm{Ca}$ and $\mathrm{Mg}$ in five different forest types. Different lower case and uppercase letters indicate significant differences among forest types, respectively, for the $\mathrm{O}$ horizon and A horizon. ${ }^{* * *}$ indicates significant differences between the $\mathrm{O}$ and A horizon at $p<0.001$.

The O horizon of Sc_Pi mixed stands showed significantly larger amounts of SOC, TN, and $\mathrm{NH}_{4}-\mathrm{N}$ than were detected in $\mathrm{O}$ horizon samples from other forest types, while, within the A horizon, the highest values of SOC were observed in both $\mathrm{Ci}$ and $\mathrm{Sc} \_\mathrm{Pi}$, with the highest TN in $\mathrm{Ci}$ (Figure 2). Soils from pure $\mathrm{Ci}$ stands showed the greatest $\mathrm{NO}_{3}-\mathrm{N}$ content for both the $\mathrm{A}$ and $\mathrm{O}$ horizons across all forest types. The lowest concentration of $\mathrm{NO}_{3}-\mathrm{N}$ was measured within A horizon soils from Sc_Pi mixed stands. Within pure stands of Sc for both horizons, we detected the lowest levels of total soil P and K (Figure 2; Table S1).

Within O horizon soils, SMBC was greatest within mixed Ci_Pi stands. SMBC values for pure stands of Pi were less than half of the values for SMBC detected within mixed Ci_Pi stands $(p=0.006)$. SMBC values for Sc stands were less than one third of what were found in Ci_Pi stands $(p<0.001)$. Within A horizon soils, no detectable differences in SMBC were observed among forest types. 


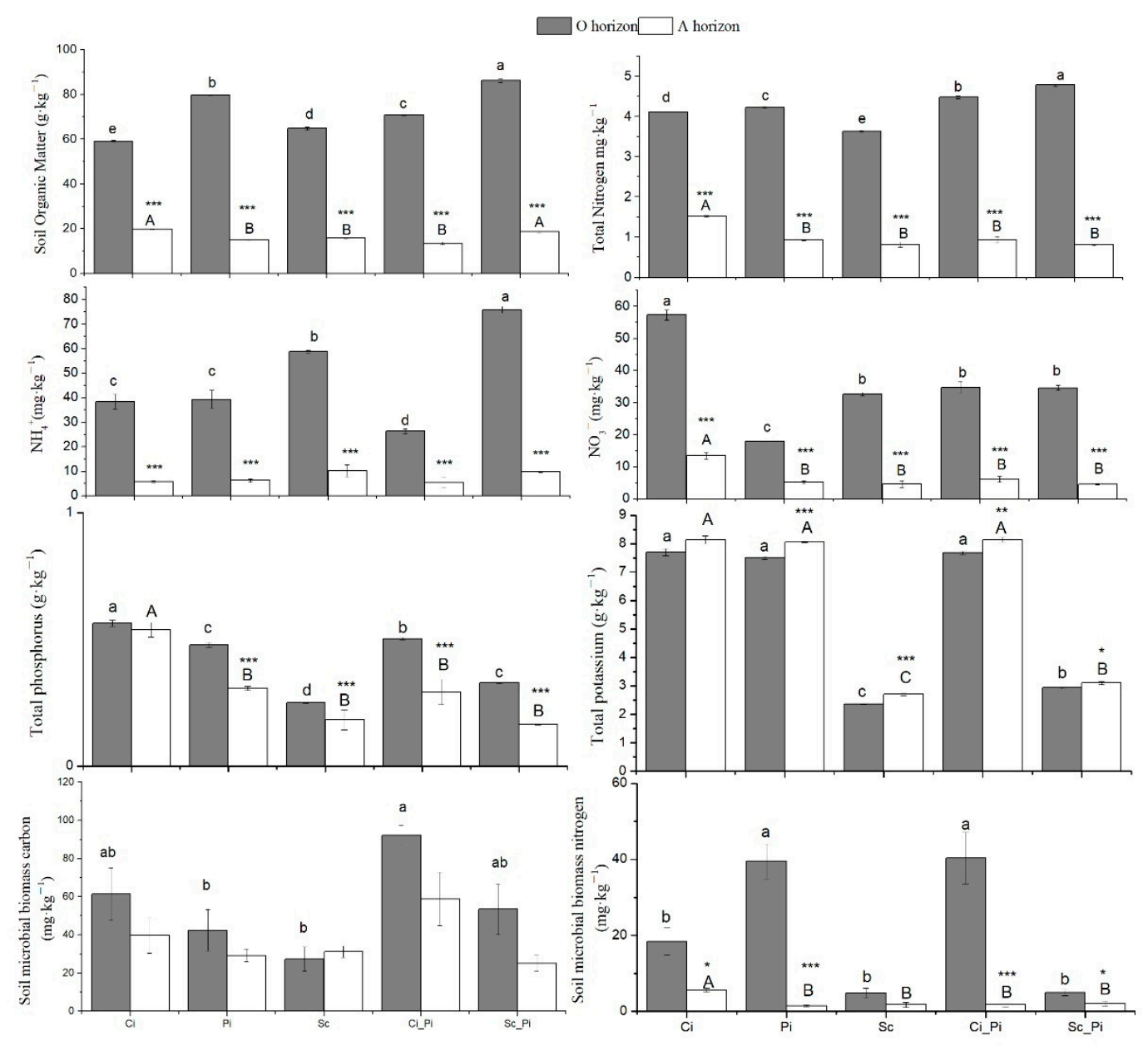

Figure 2. Soil nutrients and microbial biomass in five different forest types. Different lowercase and uppercase letters indicate significant differences among forest types, respectively, for the O horizon and A horizon. ${ }^{* * *}{ }^{* *}$ or ${ }^{*}$ indicate significant differences between the $\mathrm{O}$ and A horizon, respectively, at $p<0.001,0.01$, or 0.05 .

For SMBN, soils from the O horizon of both pure stands of $\mathrm{Pi}$ and mixed stands of Ci_Pi showed the greatest concentrations of all forest types considered in this study. Although SMBN values from A horizon soils were generally less than the concentrations measured from O horizon soils (Table S2), the greatest concentration of SMBN was detected within the A horizon of pure Ci stands (Figure 2).

\subsection{Soil Bacterial Diversity}

We compared bacterial diversity, measured via the Shannon-Wiener and Chao 1 indices, across the soil horizon and forest type and found that pure stands of $\mathrm{Ci}$ were characterized by significantly greater bacterial diversity than was found in all other forest types across both $\mathrm{O}$ and A horizons (Table 1; hereafter, bacterial diversity). Mixed Ci_Pi stands contained the second highest levels of bacterial diversity. Pure stands of Sc showed lower bacterial diversity than was found in soils from pure stands of $\mathrm{Ci}$ for both $\mathrm{O}$ and $\mathrm{A}$ horizon soils. Pi and Sc_Pi stands contained the lowest levels of bacterial diversity across all samples. Soils from pure stands of Pi were found to have the least diverse bacterial communities, as measured by the Shannon-Wiener Index. The Chao 1 index suggested that soils from pure stands of Pi were less diverse than pure stands of $\mathrm{Ci}$ by $47 \%$ and $34 \%$, within soils from the $\mathrm{O}$ horizon and A horizon, respectively. Although soils from pure stands of Sc were found to be more diverse than pure stands of $\mathrm{Pi}$, the lowest levels of soil bacterial diversity were found in mixed stands of $\mathrm{Sc}$ and $\mathrm{Pi}$ (bacterial diversity $\mathrm{Ci}>\mathrm{Ci} \mathrm{Pi}_{\mathrm{i}}>$ 
$\mathrm{Sc}>\mathrm{Pi}>\mathrm{Sc} \_\mathrm{Pi}$; Table 1). Increasing bacterial diversity was positively correlated with soil $\mathrm{pH}(p<0.001)$ and exchangeable Ca and $\mathrm{Mg}(p=0.001$; Table S3).

Table 1. Soil bacterial diversity in five types of forests.

\begin{tabular}{ccccc}
\hline & \multicolumn{2}{c}{ Shannon-Wiener Index } & \multicolumn{2}{c}{ Chao } \\
\hline & O horizon & A horizon & O horizon & A horizon \\
$\mathrm{Pi}$ & $5.52 \pm 0.013 \mathrm{~d}$ & $5.63 \pm 0.030 \mathrm{~d}$ & $1238 \pm 30 \mathrm{~d}$ & $1462 \pm 64 \mathrm{c}$ \\
$\mathrm{Ci}$ & $6.26 \pm 0.018 \mathrm{a}$ & $6.15 \pm 0.012 \mathrm{a}$ & $2339 \pm 21 \mathrm{a}$ & $2200 \pm 33 \mathrm{a}$ \\
$\mathrm{Sc}$ & $5.79 \pm 0.006 \mathrm{c}$ & $5.76 \pm 0.019 \mathrm{c}$ & $1553 \pm 26 \mathrm{c}$ & $1415 \pm 7 \mathrm{c}$ \\
Ci_Pi & $6.17 \pm 0.023 \mathrm{~b}$ & $5.98 \pm 0.044 \mathrm{~b}$ & $2164 \pm 39 \mathrm{~b}$ & $1993 \pm 35 \mathrm{~b}$ \\
Sc_Pi & $5.47 \pm 0.011 \mathrm{~d}$ & $5.62 \pm 0.023 \mathrm{~d}$ & $1172 \pm 15 \mathrm{~d}$ & $1392 \pm 32 \mathrm{c}$ \\
\hline
\end{tabular}

The values are the means $\pm \mathrm{SE}(n=4)$. Results followed by different letters are statistically significant at the 0.05 level among different forest types in the same horizon.

\subsection{Soil Bacterial Community Structure and Composition}

We used PCoA to visualize the variation in soil bacterial communities across soil horizon and forest type (Figure 3). Results from our PERMANOVA analyses suggested the main environmental variables that significantly affected soil bacterial community structure were soil layer (i.e., horizon; $p<0.001)$ and forest type $(p<0.001)$. Bacterial communities varied significantly by forest type along PCoA1, which represented approximately $43 \%$ of the variation. The soil horizon layer was a strong predictor of bacterial community composition, as bacterial communities in our samples varied significantly along PCoA2, which represented approximately $23 \%$ of the variation. In either pure or mixed stands, all samples containing $\mathrm{Ci}$ were distinct from the other forest types. Our PCoA highlighted this striking pattern (Figure 3), illustrating that soil bacterial communities from $\mathrm{Sc}, \mathrm{Pi}$, and Sc_Pi clustered together, primarily by soil type and secondarily by soil horizon. Bacterial communities found within $\mathrm{Ci}$ and $\mathrm{Ci}$ _Pi soils were more similar to each other than they were to other soil types in similar horizon layers.

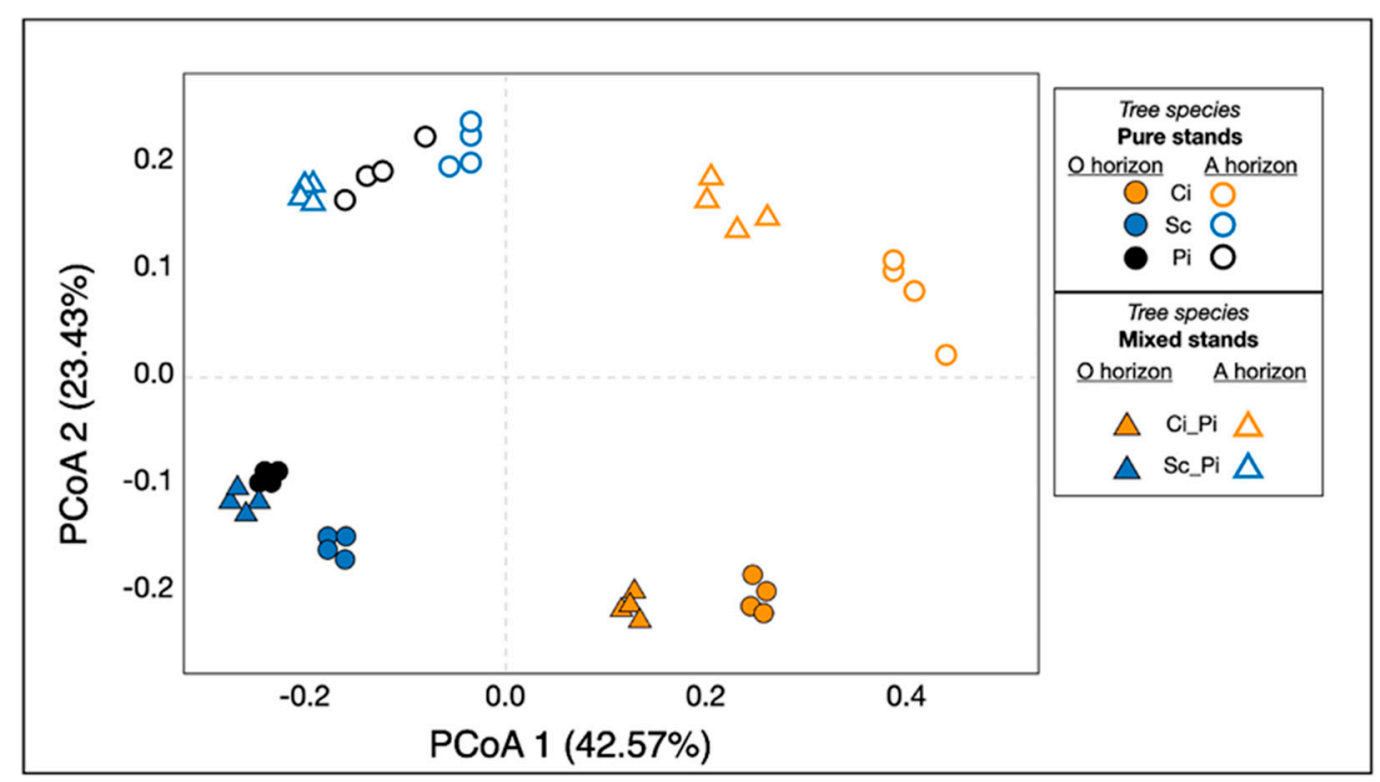

Figure 3. Principal coordinates analysis of soil bacterial communities. Samples of pure stands are shown with circular shapes, while mixed stands are shown with triangles. The shape color corresponds to tree species: pure stands of Ci and mixed stands of $\mathrm{Ci}$ are both shown as orange shapes; pure stands of Sc and mixed stands of Sc are both shown as blue shapes; pure stands of $\mathrm{Pi}$ are indicated by black shapes only. Closed shapes, filled in with the corresponding color, are shown to indicate soil from O horizons; samples shown with open shapes, with colored outlines and white space within, indicate samples from A horizons. 
The relative abundances of some taxa, such as genera Variibacter, Acidothermus, Acidibacter, and Acidobacterium and family Acidobacteriaceae, were lower in Ci and Ci_Pi than were found in Sc, Pi, and Sc_Pi (Table 2 and Figure S1). Genera Bradyrhizobium and Burkholderia, families Nitrosomonadaceae and Xanthobacteraceae, and taxa from the Acidobacteria were detected more commonly in $\mathrm{Ci}$ and $\mathrm{Ci}$ _Pi than in the other three types of forests. Many abundant bacteria were more dominant in Sc, Pi, and Sc_Pi forest types than in $\mathrm{Ci}$ and $\mathrm{Ci}$ _Pi forests, including taxa from Alphaproteobacteria: Rhodospirillales, Variibacter, Rhizomicrobium, Roseiarcus, and Acidicaldus, as well as Acidothermus, Actinobacteria, Acidimicrobiales, and Solirubrobacterales (Table 2). Notably, Bradyrhizobium canariense, Terracidiphilus, Burkholderia, Gaiellales, Chitinophagaceae, and Nitrosomonadaceae were twice as abundant in forests of $\mathrm{Ci}$ and $\mathrm{Ci}$ _Pi than in any of the other three forest types (Table 3).

In addition to the primary effect of soil layer (i.e., horizon; $p=0.001$ ) and forest type $(p=0.001)$ on determining bacterial community composition, our PERMANOVA analyses revealed a significant interaction between soil layer and forest type $(p=0.001)$. We also showed that $\mathrm{pH}, \mathrm{SOC}, \mathrm{NO}_{3}-\mathrm{N}, \mathrm{TK}$, and TP $(p=0.001)$ significantly affected the composition and structure of soil bacterial communities (Figure 4). The variation in soil properties likely corresponded to the dispersion of microbial communities along the first two axes of the RDA, which explained $57.05 \%$ and $16.19 \%$ of the variation, respectively.

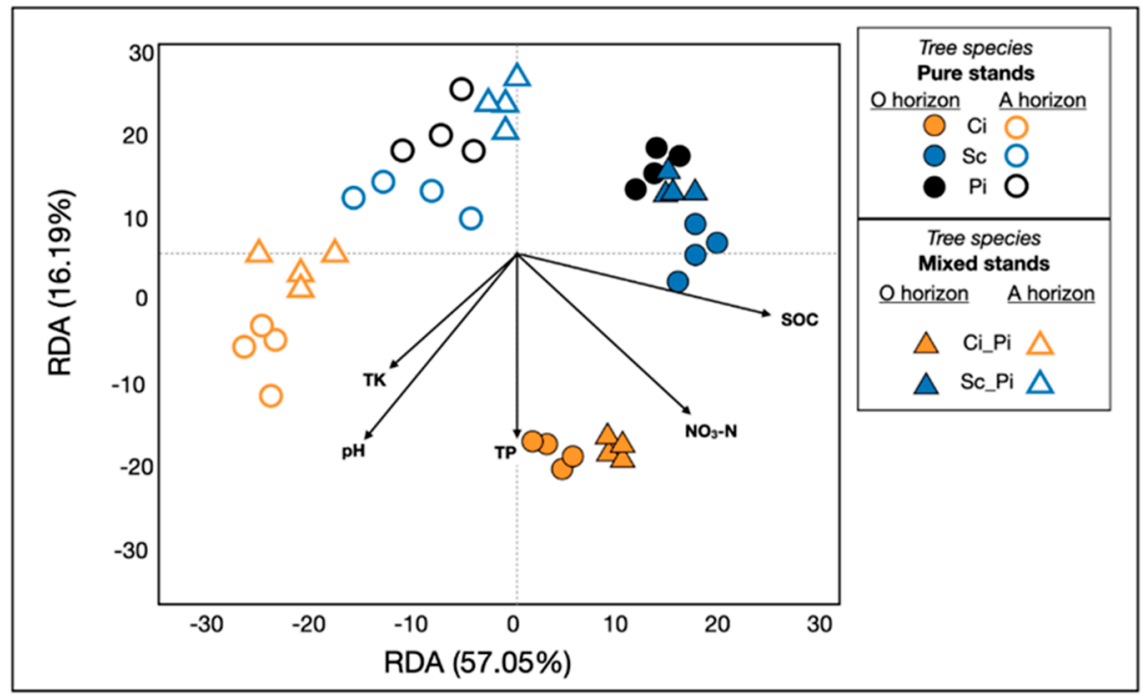

Figure 4. Redundancy analyses revealed soil bacterial communities in different forest types, their response to soil acidification, and the extent to which they correlated with edaphic properties. SOC, soil organic matter; $\mathrm{TK}=$ total potassium; $\mathrm{TP}=$ total phosphorus; $\mathrm{NO}_{3} \_\mathrm{N}=$ nitrate. As in Figure 3, samples of pure stands (circles) and mixed stands (triangles) are colored by tree species: pure and mixed stands of Ci (orange); pure and mixed stands of Sc (blue); pure stands of Pi (black). Closed shapes indicate samples from $\mathrm{O}$ horizons; open shapes represent soils collected in A horizons.

Across all forest types, the (most) abundant genera within $\mathrm{O}$ horizon soils were distinctly different from those detected within A horizon soils, a trend likely explained by significant differences in soil physicochemical properties. A horizon soils contained significantly greater $\mathrm{SOC}, \mathrm{TN}, \mathrm{TP}, \mathrm{NH}_{4}-\mathrm{N}, \mathrm{NO}_{3}-\mathrm{N}, \mathrm{Ca}, \mathrm{Mg}, \mathrm{SMBC}$, and SMBN than were found in A horizon soils (Table S2). 


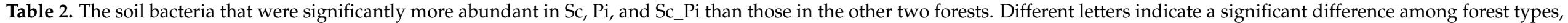
respectively in the $\mathrm{O}$ horizon and A horizon.

\begin{tabular}{|c|c|c|c|c|c|c|c|c|c|c|c|}
\hline & Rhodospirillales & Halanaerobiales & Acidimicrobiales & Solirubrobacterales & Acidibacter & Variibacter & Acidothermus & Rhizomicrobium & Acidobacterium & Roseiarcus & Acidicaldus \\
\hline \multicolumn{12}{|c|}{ O horizon } \\
\hline $\mathrm{Ci}$ & $3.12 \mathrm{c}$ & $0.98 \mathrm{c}$ & $1.65 c$ & $0.61 \mathrm{~d}$ & $3.43 \mathrm{~b}$ & $4.14 \mathrm{~b}$ & $2.42 \mathrm{c}$ & $2.43 \mathrm{~b}$ & $0.43 e$ & $1.24 \mathrm{c}$ & $0.43 c$ \\
\hline $\mathrm{Pi}$ & $5.88 \mathrm{a}$ & $2.92 a$ & $3.29 \mathrm{a}$ & $1.45 \mathrm{ab}$ & $7.46 a$ & $7.10 \mathrm{a}$ & $8.15 a$ & $3.22 \mathrm{a}$ & $3.17 \mathrm{~b}$ & $1.70 \mathrm{bc}$ & $1.10 \mathrm{a}$ \\
\hline Ci_Pi & $2.97 \mathrm{c}$ & $1.73 \mathrm{~b}$ & $2.04 \mathrm{bc}$ & $0.96 \mathrm{~cd}$ & $3.50 \mathrm{~b}$ & $5.09 \mathrm{~b}$ & $3.23 \mathrm{c}$ & $3.09 \mathrm{ab}$ & $1.05 \mathrm{~d}$ & $1.39 \mathrm{c}$ & $0.67 \mathrm{~b}$ \\
\hline Sc_Pi & $5.05 a$ & $3.11 \mathrm{a}$ & $2.45 \mathrm{~b}$ & $1.19 \mathrm{bc}$ & $8.53 a$ & $6.30 \mathrm{a}$ & $6.50 \mathrm{~b}$ & $3.77 \mathrm{a}$ & $3.51 \mathrm{a}$ & $2.40 \mathrm{a}$ & $0.74 \mathrm{~b}$ \\
\hline \multicolumn{12}{|c|}{ A horizon } \\
\hline $\mathrm{Ci}$ & $3.22 \mathrm{c}$ & $0.49 \mathrm{~d}$ & $0.84 \mathrm{c}$ & $0.17 \mathrm{~b}$ & $1.85 \mathrm{c}$ & $2.51 \mathrm{~b}$ & $0.87 \mathrm{c}$ & $1.67 \mathrm{~b}$ & $0.11 \mathrm{c}$ & $0.40 \mathrm{~b}$ & $0.11 \mathrm{c}$ \\
\hline Sc & $5.46 \mathrm{~b}$ & $2.16 \mathrm{~b}$ & $1.65 \mathrm{a}$ & $0.28 \mathrm{~b}$ & $3.78 \mathrm{~b}$ & $4.94 a$ & $4.47 \mathrm{a}$ & $1.60 \mathrm{~b}$ & $1.05 \mathrm{~b}$ & $0.82 \mathrm{ab}$ & $0.40 \mathrm{ab}$ \\
\hline $\mathrm{Ci} \mathrm{Pi}_{\mathrm{H}}$ & $5.29 \mathrm{~b}$ & $1.19 \mathrm{c}$ & $0.96 \mathrm{bc}$ & $0.26 \mathrm{~b}$ & $2.90 \mathrm{bc}$ & $2.87 \mathrm{~b}$ & $1.95 \mathrm{c}$ & $2.00 \mathrm{ab}$ & $0.41 \mathrm{c}$ & $0.52 b$ & $0.35 \mathrm{~b}$ \\
\hline Sc_Pi & $10.05 a$ & $3.19 a$ & $1.88 \mathrm{a}$ & $0.52 \mathrm{a}$ & $6.90 \mathrm{a}$ & $4.22 \mathrm{ab}$ & $4.03 \mathrm{ab}$ & $2.09 \mathrm{ab}$ & $2.55 a$ & $1.08 \mathrm{a}$ & $0.48 \mathrm{a}$ \\
\hline
\end{tabular}

The values are the means \pm SE $(n=4)$. Results followed by different letters are statistically significant at the 0.05 level among different forest types in the same horizon.

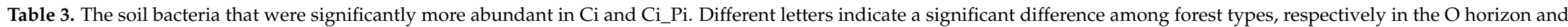
A horizon.

\begin{tabular}{|c|c|c|c|c|c|c|}
\hline & Bradyrhizobium canariense & Gaiellales & Chitinophagaceae & Nitrosomonadaceae & Terracidiphilus & Burkholderia \\
\hline & & & O horizon & & & \\
\hline $\mathrm{Ci}$ & $4.07 \pm 0.280 a$ & $2.93 \pm 0.198 a$ & $1.26 \pm 0.108 a$ & $1.42 \pm 0.036 a$ & $1.01 \pm 0.029 b$ & $1.93 \pm 0.334 a$ \\
\hline $\mathrm{Pi}$ & $1.45 \pm 0.065 c$ & $0.61 \pm 0.082 \mathrm{c}$ & $0.58 \pm 0.067 b$ & $0.018 \pm 0.007 \mathrm{c}$ & $0.71 \pm 0.014 c$ & $0.50 \pm 0.060 \mathrm{~b}$ \\
\hline Ci_Pi & $4.75 \pm 0.249 a$ & $2.24 \pm 0.146 b$ & $1.49 \pm 0.092 \mathrm{a}$ & $0.84 \pm 0.067 \mathrm{~b}$ & $1.39 \pm 0.060 \mathrm{a}$ & $2.87 \pm 0.262 \mathrm{a}$ \\
\hline Sc_Pi & $0.94 \pm 0.081 c$ & $0.27 \pm 0.024 c$ & $\begin{array}{c}0.56 \pm 0.029 b \\
\text { A horizon }\end{array}$ & $0.00 \pm 0.00 \mathrm{c}$ & $0.75 \pm 0.086 c$ & $0.45 \pm 0.056 b$ \\
\hline $\mathrm{Ci}$ & $2.07 \pm 0.063 a$ & $0.92 \pm 0.121 \mathrm{a}$ & $0.65 \pm 0.10 \mathrm{a}$ & $1.81 \pm 0.501 \mathrm{a}$ & $0.69 \pm 0.048 b$ & $0.61 \pm 0.069$ \\
\hline Sc & $1.11 \pm 0.111 b$ & $0.22 \pm 0.028 b$ & $0.25 \pm 0.032 b$ & $0.00 \pm 0.00 \mathrm{~b}$ & $1.36 \pm 0.135 a$ & $0.16 \pm 0.023$ \\
\hline Ci_Pi & $2.26 \pm 0.146 a$ & $0.99 \pm 0.072 \mathrm{a}$ & $0.63 \pm 0.067 \mathrm{a}$ & $0.37 \pm 0.099 b$ & $1.48 \pm 0.131 \mathrm{a}$ & $0.87 \pm 0.038$ \\
\hline Sc_Pi & $0.94 \pm 0.073 b$ & $0.35 \pm 0.032 b$ & $0.28 \pm 0.030 \mathrm{~b}$ & $0.00 \pm 0.00 \mathrm{~b}$ & $1.20 \pm 0.011 \mathrm{a}$ & $0.40 \pm 0.070$ \\
\hline
\end{tabular}

The values are the means \pm SE $(n=4)$. Results followed by different letters are statistically significant at the 0.05 level among different forest types in the same horizon. 
Soils from pure $\mathrm{Ci}$ and mixed $\mathrm{Ci}$ _Pi stands were associated with higher $\mathrm{pH}$ and greater amounts of exchangeable $\mathrm{Ca}$ and $\mathrm{Mg}$ ions than were found in soils from pure stands of Sc and Pi and mixed stands of Sc_Pi (Table S1). We examined the effects of soil edaphic properties on specific bacterial genera by comparing Spearman's rank correlations. We detected that the abundances of particular bacterial genera found in soils from $\mathrm{Sc}, \mathrm{Pi}$, and Sc_Pi were negatively correlated with both soil pH and TK (Table S4). For instance, the relative abundances of Rhodospirillales, Halanaerobiales, Acidibacter, Acidothermus, and Acidobacterium were negatively correlated with both TP and TK, with the exception of Rhodospirillales, which was not correlated with TK concentrations. Besides Rhodospirillales and Halanaerobiales, relative abundances of particular bacterial taxa were positively correlated with $\mathrm{NH}_{4}-\mathrm{N}$, including Acidibacter, Acidothermus, Acidobacterium, Acidicaldus, Roseiarcus, Variibacter, and Rhizomicrobium (Table S4). Although the relative abundances of the most abundant taxa (Bradyrhizobium, Gaiellales, Chitinophagaceae, and Nitrosomonadaceae) in $\mathrm{Ci}$ and $\mathrm{Ci} \_\mathrm{Pi}$ were positively correlated with soil $\mathrm{pH}, \mathrm{Ca}, \mathrm{Mg}, \mathrm{TP}, \mathrm{TK}, \mathrm{NO}_{3}-\mathrm{N}$, and TN (except for Nitrosomonadaceae), the relative abundance of Burkholderia was only positively correlated with $\mathrm{pH}, \mathrm{Ca}$, and $\mathrm{Mg}$. Additionally, the abundance of Terracidiphilus was positively correlated with only $\mathrm{pH}, \mathrm{Ca}, \mathrm{Mg}, \mathrm{TP}, \mathrm{TK}$, and $\mathrm{NH}_{4}-\mathrm{N}$ (Table S5).

\section{Discussion}

The term soil acidification-and recovery from acidification-refers to a complex set of processes and, thus, cannot be quantitatively described by a single index [8]. Soil pH is, perhaps, the most important driver of soil properties, as soil $\mathrm{pH}$ is probably the single most informative measurement that can be made to determine soil characteristics [46] and is directly affected by acid deposition. Within the Tieshanping study site, pure stands of $\mathrm{Ci}$ were characterized by significantly greater soil $\mathrm{pH}$ followed by mixed stands of $\mathrm{Ci} \_\mathrm{Pi}$, as compared to pure stands of $\mathrm{Pi}$ and $\mathrm{Sc}$ and mixed stands of Sc_Pi. Likewise, the bacterial communities associated with both $\mathrm{Ci}$ and $\mathrm{Ci}$ _Pi were distinct from the soil bacterial communities found in the other forest types in our study. Previous work has shown that $\mathrm{pH}$ is an important predictor of soil bacterial communities [47], which suggests that $\mathrm{pH}$ may have strongly driven bacterial community structure in forests containing $\mathrm{Ci}$, which also corresponded to less acidic conditions.

Comparing concentrations of exchangeable base cations within different forest type soils elucidates their varied capacities for ameliorating acidification. Plantations in Tieshanping that contained either pure $\mathrm{Ci}$ stands or mixed stands of Ci_Pi had greater amounts of base cations, and therefore increased ability to adapt to acidic soil and improved soil quality as compared with other plantation types. This may result from greater inputs of exchangeable $\mathrm{Ca}$ and $\mathrm{Mg}$ released to soils from decomposing $\mathrm{Ci}$ litter than those released from decomposing Pi litter. Increasing inputs of $\mathrm{Ca}$ and $\mathrm{Mg}$ are likely to improve soil-buffering capacity and reduce acidity (e.g., from P. massoniana; Mason pine; [25]). This observation is supported by previous studies that have shown that tree species producing more Caenriched litter are often associated with lower soil acidity and higher forest floor turnover rates [22,24]. Furthermore, higher rates of litter turnover, as observed in stands planted with $\mathrm{Ci}$, would likewise promote a faster return of base cations (i.e., exchangeable $\mathrm{Ca}$ and $\mathrm{Mg}$ ) to forest soils, and therefore reduce the likelihood of further soil acidification [23].

Depending on the tree species planted, acidic stress may either be ameliorated or exacerbated. Our results showed that soils from $\mathrm{O}$ horizons in pure stands planted with $\mathrm{Ci}$ had the highest soil $\mathrm{pH}$ and greatest concentrations of $\mathrm{NO}_{3}{ }^{-}$and $\mathrm{TP}$, and soils from O horizons in mixed stands of Ci_Pi had the greatest concentrations of $\mathrm{Ca}, \mathrm{Mg}$, TK, and SMBC. Yet, in A horizon, soils from mixed stands of Ci_Pi were found to have the highest soil $\mathrm{pH}$ and concentrations of $\mathrm{Ca}, \mathrm{Mg}, \mathrm{SOC}, \mathrm{TN}, \mathrm{TP}$, and $\mathrm{NO}_{3}{ }^{-}$. In contrast, plantations containing Sc did not appear to improve acidic conditions or soil quality. Soils containing $\mathrm{Sc}$ had lower soil $\mathrm{pH}$ and less exchangeable $\mathrm{Ca}$ and $\mathrm{Mg}$ than plantations planted with different tree species, which suggests that Sc plantations may yield important effects on soil properties and even exacerbate soil acidification. These findings addressed our first 
question, as soil quality appeared to be higher in stands planted with $\mathrm{Ci}$; this was likely due to improvements in base cation exchange, while soil quality was lower in plantations containing Sc.

Microbial communities found within acidic soils and therefore exposed to particularly severe environmental stress may be characterized by unique bacterial assemblages. In our study, we demonstrated how bacterial diversity and community composition varied across five acid rain-exposed forest types in the Tieshanping region of China to evaluate the relationship between plantation type and the accompanying bacterial community, which may relate to soil acidity over time. We found that forests planted with pure $\mathrm{Ci}$ and mixed Ci_Pi corresponded to less acidic soils, greater concentrations of exchangeable $\mathrm{Ca}$ and $\mathrm{Mg}$, and greater bacterial diversity (species richness) within both the $\mathrm{O}$ horizon and $\mathrm{A}$ horizon, as compared to plots planted with pure Pi, Sc, or combined Sc_Pi. A strong positive correlation between bacterial alpha diversity and both increasing soil $\mathrm{pH}$ and concentrations of $\mathrm{Ca}$ and $\mathrm{Mg}$ suggested that a greater proportion of the identified bacterial taxa may be functionally redundant [48]. Moreover, with a greater diversity of taxa, there may be a greater chance of containing suites of microorganisms with metabolic strategies that modify ecosystem processes and illustrate traits that are conducive to improving soil health by reducing soil acidity and environmental stress.

Our findings suggested that soil bacterial communities associated with $\mathrm{Ci}$ and Ci_Pi plantings were structurally different from those present in Sc-, $\mathrm{Pi}$-, and $\mathrm{Sc}$-Pi-planted soils. Because of this divergence, a portion of the taxa present or absent from these soils may have contributed to driving compositional patterns in bacterial communities. This finding illustrates the inextricable link between above- and below-ground communities [49], especially the influence of tree species on belowground microbial community assemblages [50]. In this study, the more abundant taxa associated with $\mathrm{Sc}, \mathrm{Pi}$, and Sc_Pi stands were negatively correlated with $\mathrm{pH}$; yet, only two of these taxonomic orders, as either acidophilic and acid-producing taxa, were found to be negatively correlated with exchangeable $\mathrm{Ca}$ and $\mathrm{Mg}$.

The relative abundance of acidophilic and acid-producing taxa varied across forest types. One important taxon, Rhodospirillales, which contains several acidophilic genera, was very abundant in all soil samples. One commonly occurring feature of this order is aerobic oxidation of ethanol to acetic acid and the accumulation of acetic acid within the medium [51]. The abundance of Rhodospirillales was negatively correlated with soil $\mathrm{pH}$ and was shown to be more abundant in more acidic soils. Moreover, acetic acid produced by Rhodospirillales may accumulate within host soils, further decreasing soil $\mathrm{pH}$. Halanaerobiales are anaerobes with a fermentative or homoacetogenic metabolism, which also produce acetate as a primary end-product of their metabolic process [52]. An excess of acidic amino acids can be formed in whole-cell hydrolysates of selected members of this order [53], leading to further acidification of soils. Therefore, it can be inferred that an abundance of Halanaerobiales and Rhodospirillales would likely aggravate soil acidity to a greater extent, as was observed in $\mathrm{Sc}, \mathrm{Pi}$, and $\mathrm{Sc} \_\mathrm{Pi}$ soils as compared to those from $\mathrm{C} i$ and $\mathrm{Ci}$ _Pi stands. In soils from $\mathrm{Sc}, \mathrm{Pi}$, and $\mathrm{Sc} \_\mathrm{Pi}$ plantings, greater abundances of Acidibacter [54], Acidobacterium [55], Roseiarcus [56], Variibacter [57], Acidicaldus [58], and Rhizomicrobium [59] were observed. Therefore, more acidic soils harbored more abundant acidophilic bacteria.

We found lower abundances of acidophilic and acid-producing taxa and greater abundances of more beneficial taxa in $\mathrm{Ci}$ and $\mathrm{Ci} \mathrm{Pi}_{\mathrm{P}}$, including some that may have contributed to soil aggregate formation and heightened environmental stress resistance. Groups of bacteria that were more abundant in $\mathrm{Ci}$ and $\mathrm{Ci}$ _Pi were also shown to be positively correlated with greater soil $\mathrm{pH}$ and exchangeable $\mathrm{Ca}$ and $\mathrm{Mg}$. We found the relative abundance of Bradyrhizobium canariense, a species of endosymbiont nitrogen-fixing bacterium with acid tolerance [60], was highly abundant in all soils, and notably three to four times as abundant within Ci and Ci_Pi soils, respectively, than was detected in soils from the other forest types. The genus Terracidiphilus produces extracellular enzymes implicated in the degradation of plant-derived oligosaccharides and chitin [61]. Both Bradyrhizobium ca- 
nariense and Terracidiphilus produce large amounts of external exopolysaccharides, which play an important role in soil aggregate formation and also serve as carbon sources for microbes $[60,61]$. Improved soil aggregation, in combination with an abundance of carbon sources, helps to improve soil quality and plant growth [62]. Previous studies have shown that Gaiellales is a cryptic microbe (one family, Gaiellaceae, containing only one genus: Gaiella, as well as just a single species) that persists at an optimum pH between 6.5 and 7.5 and will not grow at $\mathrm{pH} 5.0$ [63]. The existence of Gaiellales in our study within soils with a $\mathrm{pH}$ less than five may indicate either an ecotypic variation or a new species with distinct physiological niche structure. Certain genes of Gaiellales are involved in the tricarboxylic acid cycle, gluconeogenesis, and pentose phosphate pathway, which not only affects soil carbon, but is also involved in reactive oxygen species detoxification [64] and may contribute to increased environmental stress resistance. Nitrosomonadaceae comprises a group of ammonia oxidizers, which play a major role in controlling the nitrogen cycle [65]. As the relative abundance of Nitrosomonadaceae was found to be positively correlated with the soil $\mathrm{NO}_{3}{ }^{-}$concentrations $(p<0.001)$, this greater abundance of Nitrosomonadaceae in $\mathrm{Ci}$ and Ci_Pi soils may lead to improvements in nitrification processes.

Low soil $\mathrm{pH}$ was likely receptive to both acid-tolerant and acidophilic bacteria. Conversely, some abundant acidophilic taxa, such as Halanaerobiales and Rhodospirillales, may yield more acid and thereby further decrease soil $\mathrm{pH}$. We detected more abundant acidophilic taxa in soils from $\mathrm{Sc}, \mathrm{Pi}$, and $\mathrm{Sc} \_\mathrm{Pi}$, which were distinctly different from $\mathrm{Ci}$ and Ci_Pi soil bacterial communities. Thus, as the effects of planted tree species extends beyond the vegetation community to affect soil edaphic factors and belowground communities, the findings from our study showcased a series of complex linkages revealed between soil acidity and soil bacterial community composition.

\section{Conclusions}

Our findings confirmed that pure plantations of $\mathrm{Ci}$ or mixed plantations of $\mathrm{Ci}$ and $\mathrm{Pi}$ in acidic soils could be beneficial for improving soil quality. In contrast, Sc plantings did not improve severely degraded Pi forests with acidic soils. Instead, these soils may continue to acidify despite declining acid deposition. Differences in soil bacterial community structures may partly explain this phenomenon as driven by bacterial metabolic processes, which result in further additions of acetic acid and amino acids to host soils. Acidophilic acid-producing taxa that were more abundant in stands planted with Sc may cause additional accumulations of organic acids, which further decrease soil $\mathrm{pH}$. Furthermore, slight reductions in soil acidity in stands planted with Ci may result from increased soil-buffering capacity, augmented by additional Ca- and Mg-enriched Ci litter. Further studies are needed to better understand plant and soil microbial community interactions that may affect, or possibly ameliorate, soil acidity across a variety of different forest types.

Supplementary Materials: The following are available online at https: / www.mdpi.com/article / 10.3390/f12060657/s1, Figure S1: Soil bacterial community heatmap analysis of the top 50 genera. Samples with the letter "O" mean soil from the O horizon; samples with the letter " $\mathrm{A}$ " mean soil from the A horizon. Table S1: The soil properties in different forest types regardless of soil depth. Table S2: The difference of soil properties between the O horizon and A horizon regardless of forest type. Table S3: The relationship among soil bacterial alpha diversity and soil $\mathrm{pH}, \mathrm{Ca}$, and $\mathrm{Mg}$. Table S4: The relationship among soil properties and the more abundant bacteria in Sc, Pi, and Sc_Pi. Table S5: Correlation among soil properties and the more abundant bacteria in Ci and Ci_Pi.

Author Contributions: Conceptualization, Z.C. and J.C.; methodology, Z.C., M.R.M., Y.Z., and Y.W.; investigation, Z.C. and Y.W.; data curation, Z.C.; writing-original draft preparation, Z.C.; writingreview and editing, Y.Z., M.R.M., B.J.O., and M.N.; project administration, Z.C.; funding acquisition, Z.C. All authors read and agreed to the published version of the manuscript.

Funding: This research was funded by the Fundamental Research Funds for the Central Non-profit Research Institution of CAF (CAFYBB2018SZ004) and the National Natural Science Foundation of China (31971630). 
Data Availability Statement: The data presented in this study are available upon request from the corresponding author.

Acknowledgments: The authors appreciate Tieshanping Forest Park of Chongqing for helping with the field work. We recognize the University of California Office of the President Fellowship to M.M. and support from Metabolic Studio to CoRenewal Incorporated, and dedicated volunteer service from B.O., M.M., and M.N to CoRenewal Incorporated. We are also grateful to Mingquan Zou and Qian Zhang for their contribution to the field sampling and soil analysis.

Conflicts of Interest: The authors declare no conflict of interest. Co-authors affiliated with CoRenewal Incorporated are disinterested members of the organization's Board of Directors and have not received any financial compensation for their service to the organization; CoRenewal has not contributed any financial support to this study and therefore declares no conflict of interest with the design, execution, interpretation, or writing of this research project.

\section{References}

1. Duan, L.; Yu, Q.; Zhang, Q.; Wang, Z.; Pan, Y.; Larssen, T.; Tang, J.; Mulder, J. Acid deposition in Asia: Emissions, deposition, and ecosystem effects. Atmos. Environ. 2016, 146, 55-69. [CrossRef]

2. Yu, H.; He, N.; Wang, Q.; Zhu, J.; Gao, Y.; Zhang, Y.; Jia, Y.; Yu, G. Development of atmospheric acid deposition in China from the 1990s to the 2010s. Environ. Pollut. 2017, 231, 182-190. [CrossRef]

3. Wang, S.X.; Zhao, B.; Cai, S.Y.; Klimont, Z.; Nielsen, C.P.; Morikawa, T.; Woo, J.H.; Kim, Y.; Fu, X.; Xu, J.Y.; et al. Emission trends and mitigation options for air pollutants in East Asia. Atmos. Chem. Phys. 2014, 14, 6571-6603. [CrossRef]

4. Kang, Y.; Liu, M.; Song, Y.; Huang, X.; Yao, H.; Cai, X.; Zhang, H.; Kang, L.; Liu, X.; Yan, X.; et al. High-resolution ammonia emissions inventories in China from 1980 to 2012. Atmos. Chem. Phys. 2016, 16, 2043-2058. [CrossRef]

5. Bobbink, R.; Hicks, K.; Galloway, J.; Spranger, T.; Alkemade, R.; Ashmore, M.; Bustamante, M.; Cinderby, S.; Davidson, E.; Dentener, F.; et al. Global assessment of nitrogen deposition effects on terrestrial plant diversity: A synthesis. Ecol. Appl. 2010, 20, 30-59. [CrossRef] [PubMed]

6. Simkin, S.M.; Allen, E.B.; Bowman, W.D.; Clark, C.M.; Belnap, J.; Brooksf, M.L.; Cade, B.S.; Collins, S.L.; Geiser, L.H.; Gilliam, F.S.; et al. Conditional vulnerability of plant diversity to Atmospheric nitrogen deposition across the United States. Proc. Natl. Acad. Sci. USA 2016, 113, 4086-4091. [CrossRef]

7. Huang, Y.; Kang, R.; Mulder, J.; Zhang, T.; Duan, L. Nitrogen saturation, soil acidification, and ecological effects in a subtropical pine forest on acid soil in southwest China. J. Geophys. Res. G Biogeosci. 2015, 120, 2457-2472. [CrossRef]

8. Berger, T.W.; Türtscher, S.; Berger, P.; Lindebner, L. A slight recovery of soils from Acid Rain over the last three decades is not reflected in the macro nutrition of beech (Fagus sylvatica) at 97 forest stands of the Vienna Woods. Environ. Pollut. 2016, 216, 624-635. [CrossRef]

9. Maltz, M.R.; Chen, Z.; Cao, J.; Arogyaswamy, K.; Shulman, H.; Aronson, E.L. Inoculation with Pisolithus tinctorius may ameliorate acid rain impacts on soil microbial communities associated with Pinus massoniana seedlings. Fungal Ecol. 2019, 40, 50-61. [CrossRef]

10. Graf Pannatier, E.; Thimonier, A.; Schmitt, M.; Walthert, L.; Waldner, P. A decade of monitoring at Swiss Long-Term Forest Ecosystem Research (LWF) sites: Can we observe trends in atmospheric acid deposition and in soil solution acidity? Environ. Monit. Assess. 2011, 174, 3-30. [CrossRef]

11. Marx, A.; Hintze, S.; Sanda, M.; Jankovec, J.; Oulehle, F.; Dusek, J.; Vitvar, T.; Vogel, T.; van Geldern, R.; Barth, J.A.C. Acid rain footprint three decades after peak deposition: Long-term recovery from pollutant sulphate in the Uhlirska catchment (Czech Republic). Sci. Total Environ. 2017, 598, 1037-1049. [CrossRef] [PubMed]

12. Chen, X.Y.; Mulder, J. Atmospheric deposition of nitrogen at five subtropical forested sites in South China. Sci. Total Environ. 2007, 378, 317-330. [CrossRef] [PubMed]

13. Fang, Y.; Gundersen, P.; Vogt, R.D.; Koba, K.; Chen, F.; Chen, X.Y.; Yoh, M. Atmospheric deposition and leaching of nitrogen in Chinese forest ecosystems. J. For. Res. 2011, 16, 341-350. [CrossRef]

14. Tian, D.; Niu, S. A global analysis of soil acidification caused by nitrogen addition. Environ. Res. Lett. 2015, 10, 024019. [CrossRef]

15. Smith, S.; Read, D. Mycorrhizal Symbiosis; Academic: San Diego, CA, USA, 2008. [CrossRef]

16. Gruba, P.; Mulder, J. Tree species affect cation exchange capacity (CEC) and cation binding properties of organic matter in acid forest soils. Sci. Total Environ. 2015, 511, 655-662. [CrossRef]

17. Sayer, E.J. Using experimental manipulation to assess the roles of leaf litter in the functioning of forest ecosystems. Biol. Rev. Camb. Philos. Soc. 2006, 81, 1-31. [CrossRef]

18. Baar, J.; Ter Braak, C.J.F. Ectomycorrhizal sporocarp occurrence as affected by manipulation of litter and humus layers in scots pine stands of different age. Appl. Soil Ecol. 1996, 4, 61-73. [CrossRef]

19. Mo, J.; Brown, S.; Peng, S.; Kong, G. Nitrogen availability in disturbed, rehabilitated and mature forests of tropical China. For. Ecol. Manag. 2003, 175, 573-583. [CrossRef]

20. Dzwonko, Z.; Gawroński, S. Effect of litter removal on species richness and acidification of a mixed oak-pine woodland. Biol. Conserv. 2002, 106, 389-398. [CrossRef] 
21. Mueller, K.E.; Eissenstat, D.M.; Hobbie, S.E.; Oleksyn, J.; Jagodzinski, A.M.; Reich, P.B.; Chadwick, O.A.; Chorover, J. Tree species effects on coupled cycles of carbon, nitrogen, and acidity in mineral soils at a common garden experiment. Biogeochemistry 2012, 111, 601-614. [CrossRef]

22. De Schrijver, A.; De Frenne, P.; Staelens, J.; Verstraeten, G.; Muys, B.; Vesterdal, L.; Wuyts, K.; van Nevel, L.; Schelfhout, S.; De Neve, S.; et al. Tree species traits cause divergence in soil acidification during four decades of postagricultural forest development. Glob. Chang. Biol. 2012, 18, 1127-1140. [CrossRef]

23. Van Nevel, L.; Mertens, J.; De Schrijver, A.; Baeten, L.; De Neve, S.; Tack, F.M.G.; Meers, E.; Verheyen, K. Forest floor leachate fluxes under six different tree species on a metal contaminated site. Sci. Total Environ. 2013, 447, 99-107. [CrossRef]

24. Schelfhout, S.; Mertens, J.; Verheyen, K.; Vesterdal, L.; Baeten, L.; Muys, B.; De Schrijver, A. Tree species identity shapes earthworm communities. Forests 2017, 8, 85. [CrossRef]

25. Ma, Z.L.; Gao, S.; Yang, W.Q.; Wu, F.Z. Seasonal release characteristics of Ca, Mg and Mn of foliar litter of six tree species in subtropical evergreen broadleaved forest. Chin. J. Appl. Ecol. 2015, 26, 2913-2920.

26. Finzi, A.C.; Van Breemen, N.; Canham, C.D. Canopy tree-soil interactions within temperate forests: Species effects on soil carbon and nitrogen. Ecol. Appl. 1998, 8, 440-446. [CrossRef]

27. Currie, W.S.; Aber, J.D.; Mcdowell, W.H.; Boone, R.D.; Magill, A.H. Vertical transport of dissolved organic C and N under long-term $\mathrm{N}$ amendments in pine and hardwood forests. Biogeochemistry 1996, 35, 471-505. [CrossRef]

28. Fröberg, M.; Hansson, K.; Kleja, D.B.; Alavi, G. Dissolved organic carbon and nitrogen leaching from Scots pine, Norway spruce and silver birch stands in southern Sweden. For. Ecol. Manag. 2011, 262, 1742-1747. [CrossRef]

29. Lindroos, A.J.; Derome, J.; Derome, K.; Smolander, A. The effect of scots pine, norway spruce and silver birch on the chemical composition of stand throughfall and upper soil percolation water in northern Finland. Boreal Environ. Res. 2011, 16, $240-250$.

30. Yu, X.L. The Buffering Capacity of Acid Rain and Its Chemical Composition Research of Common Species Forest Litter Leaves in Subtropical Area. Master's Thesis, Zhejiang A\&F University, Hangzhou, China, 2011.

31. Li, Z.; Chen, J.; Wang, Y.; Yu, P.; Du, S.; He, P.; Duan, J. Effects of Schima superba plantations on soil chemical properties in the acid rain region of Chongqing, southwestern China. J. Plant Ecol. 2008, 32, 632-638, (In Chinese with English Abstract).

32. Wang, L.; Chen, Z.; Shang, H.; Wang, J.; Zhang, P.Y. Impact of simulated acid rain on soil microbial community function in Masson pine seedlings. Electron. J. Biotechnol. 2014, 17, 199-203. [CrossRef]

33. Zhang, X.; Liu, W.; Zhang, G.; Jiang, L.; Han, X. Mechanisms of soil acidification reducing bacterial diversity. Soil Biol. Biochem. 2015, 81, 275. [CrossRef]

34. Li, Y.; Chen, Z.; He, J.Z.; Wang, Q.; Shen, C.; Ge, Y. Ectomycorrhizal fungi inoculation alleviates simulated acid rain effects on soil ammonia oxidizers and denitrifiers in Masson pine forest. Environ. Microbiol. 2019, 21, 299-313. [CrossRef] [PubMed]

35. Xu, H.Q.; Zhang, J.E.; Ouyang, Y.; Lin, L.; Quan, G.M.; Zhao, B.L.; Yu, J.Y. Effects of simulated acid rain on microbial characteristics in a lateritic red soil. Environ. Sci. Pollut. Res. 2015, 22, 18260-18266. [CrossRef]

36. Liu, X.; Zhang, B.; Zhao, W.; Wang, L.; Xie, D.; Huo, W.; Wu, Y.; Zhang, J. Comparative effects of sulfuric and nitric acid rain on litter decomposition and soil microbial community in subtropical plantation of Yangtze River Delta region. Sci. Total Environ. 2017, 601-602, 669-678. [CrossRef]

37. Larssen, T.; Lydersen, E.; Tang, D.; He, Y.; Gao, J.; Liu, H.; Duan, L.; Seip, H.M.; Vogt, R.D.; Mulder, J.; et al. Acid rain in China. Environ. Sci. Technol. 2006, 40, 418-425. [CrossRef] [PubMed]

38. Li, Z.; Wang, Y.; Liu, Y.; Guo, H.; Li, T.; Li, Z.H.; Shi, G. Long-term effects of liming on health and growth of a Masson pine stand damaged by soil acidification in Chongqing, China. PLoS ONE 2014, 9, e94230. [CrossRef]

39. Wang, Y.; Solberg, S.; Yu, P.; Myking, T.; Vogt, R.D.; Du, S. Assessments of tree crown condition of two Masson pine forests in the acid rain region in south China. For. Ecol. Manag. 2007, 242, 530-540. [CrossRef]

40. Acosta-Martínez, V.; Dowd, S.; Sun, Y.; Allen, V. Tag-encoded pyrosequencing analysis of bacterial diversity in a single soil type as affected by management and land use. Soil Biol. Biochem. 2008, 40, 2762-2770. [CrossRef]

41. Chen, X.Y.; Mulder, J. Indicators for nitrogen status and leaching in subtropical forest ecosystems, south China. Biogeochemistry 2007, 82, 165-180. [CrossRef]

42. IUSS Working Group WRB. World Reference Base for Soil Resources 2006; World Soil Resources Reports No. 103; The International Union of Soil Science: Rome, Italy, 2006.

43. Vance, E.D.; Brookes, P.C.; Jenkinson, D.S. An extraction method for measuring soil microbial biomass C. Soil Biol. Biochem. 1987, 19, 703-707. [CrossRef]

44. Anderson, M.J.; Gorley, R.N.; Clarke, K.R. PERMANOVA+ for PRIMER: Guide to Software and Statistical Methods; PRIMER-E Ltd.: Plymouth, UK, 2008; pp. 1-214.

45. Oksanen, J.; Blanchet, F.G.; Kindt, R.; Legendre, P.; Minchin, P.R.; O’Hara, R.B.; Simpson, G.L.; Solymos, P.; Henry, M.; Stevens, H.; et al. Vegan: Community Ecology Package. R Package Version 2.0-3. 2012. Available online: http://CRAN.R-project.org/ package=vegan (accessed on 8 January 2013).

46. Thomas, G.W. Soil pH and Soil Acidity. In Methods of Soil Analysis: Part 3 Chemical Methods, 5.3; Sparks, D.L., Page, A.L., Helmke, P.A., Loeppert, R.H., Soltanpour, P.N., Tabatabai, M.A., Johnston, T., Sumner, M.E., Soil Science Society of America, Inc., Eds.; American Society of Agronomy, Inc.: Madison, WI, USA, 2018; pp. 475-490. [CrossRef]

47. Fierer, N.; Jackson, R.B. The diversity and biogeography of soil bacterial communities. Proc. Natl. Acad. Sci. USA 2006, 103, 626-631. [CrossRef] [PubMed] 
48. Allison, S.D.; Martiny, J.B.H. Resistance, resilience, and redundancy in microbial communities. Proc. Natl. Acad. Sci. USA 2008, 105, 11512-11519. [CrossRef] [PubMed]

49. Wardle, D.A.; Bardgett, R.D.; Klironomos, J.N.; Setälä, H.; Van Der Putten, W.H.; Wall, D.H. Ecological linkages between aboveground and belowground biota. Science 2004, 304, 1629-1633. [CrossRef]

50. Lejon, D.P.H.; Chaussod, R.; Ranger, J.; Ranjard, L. Microbial community structure and density under different tree species in an acid forest soil (Morvan, France). Microb. Ecol. 2005, 50, 614-625. [CrossRef] [PubMed]

51. Röling, W.F.M. Hydrocarbon-Degradation by Acidophilic Microorganisms. In Handbook of Hydrocarbon and Lipid Microbiology; Springer: Berlin/Heidelberg, Germany, 2010; pp. 1923-1930. [CrossRef]

52. Singh, O.V. Extremophiles: Sustainable Resources and Biotechnological Implications; Springer: Berlin/Heidelberg, Germany, 2012. [CrossRef]

53. Bardavid, R.E.; Oren, A. The amino acid composition of proteins from anaerobic halophilic bacteria of the order Halanaerobiales. Extremophiles 2012, 16, 567-572. [CrossRef]

54. Falagán, C.; Johnson, D.B. Acidibacter ferrireducens gen. nov., sp. nov.: An acidophilic ferric iron-reducing gammaproteobacterium. Extremophiles 2014, 18, 1067-1073. [CrossRef]

55. Thrash, J.C.; Coates, J.D. Acidobacterium Bergey's Manual of Systematics of Archaea and Bacteria; John Wiley \& Sons, Inc.: Hoboken, 2015. [CrossRef]

56. Kulichevskaya, I.S.; Danilova, O.V.; Tereshina, V.M.; Kevbrin, V.V.; Dedysh, S.N. Descriptions of Roseiarcus fermentans gen nov., sp. nov., a bacteriochlorophyll a-containing fermentative bacterium related phylogenetically to alphaproteobacterial methanotrophs, and of the family Roseiarcaceae fam. nov. Int. J. Syst. Evol. Microbiol. 2014, 64, 2558-2565. [CrossRef]

57. Kim, K.K.; Lee, K.C.; Eom, M.K.; Kim, J.S.; Kim, D.S.; Ko, S.H.; Kim, B.H.; Lee, J.S. Variibacter gotjawalensis gen. nov., sp. nov., isolated from soil of a lava forest. Antonie Leeuwenhoek Int. J. Gen. Mol. Microbiol. 2014, 105, 915-924. [CrossRef] [PubMed]

58. Johnson, D.B.; Stallwood, B.; Kimura, S.; Hallberg, K.B. Isolation and characterization of Acidicaldus organivorus, gen. nov., sp. nov.: A novel sulfur-oxidizing, ferric iron-reducing thermo-acidophilic heterotrophic Proteobacterium. Arch. Microbiol. 2006, 185, 212-221. [CrossRef] [PubMed]

59. Xue, L.; Ren, H.; Li, S.; Leng, X.; Yao, X. Soil bacterial community structure and co-occurrence pattern during vegetation restoration in karst rocky desertification area. Front. Microbiol. 2017, 8, 2377. [CrossRef]

60. Stepkowski, T.; Zak, M.; Moulin, L.; Króliczak, J.; Golińska, B.; Narozna, D.; Safronova, V.I.; Madrzak, C.J. Bradyrhizobium canariense and Bradyrhizobium japonicum are the two dominant rhizobium species in root nodules of lupin and serradella plants growing in Europe. Syst. Appl. Microbiol. 2011, 34, 368-375. [CrossRef] [PubMed]

61. García-Fraile, P.; Benada, O.; Cajthaml, T.; Baldrian, P.; Lladó, S. Terracidiphilus gabretensis gen. nov., sp. nov., an abundant and active forest soil acidobacterium important in organic matter transformation. Appl. Environ. Microbiol. 2016, 82, 560-569. [CrossRef] [PubMed]

62. Costa, O.Y.A.; Raaijmakers, J.M.; Kuramae, E.E. Microbial extracellular polymeric substances: Ecological function and impact on soil aggregation. Front. Microbiol. 2018, 9, 1636. [CrossRef]

63. Albuquerque, L.; França, L.; Rainey, F.A.; Schumann, P.; Nobre, M.F.; Da Costa, M.S. Gaiella occulta gen. nov., sp. nov., a novel representative of a deep branching phylogenetic lineage within the class Actinobacteria and proposal of Gaiellaceae fam. nov. and Gaiellales ord. nov. Syst. Appl. Microbiol. 2011, 34, 595-599. [CrossRef]

64. Severino, R.; Froufe, H.J.C.; Barroso, C.; Albuquerque, L.; Lobo-da-Cunha, A.; da Costa, M.S.; Egas, C. High-quality draft genome sequence of Gaiella occulta isolated from a 150 meter deep mineral water borehole and comparison with the genome sequences of other deep-branching lineages of the phylum Actinobacteria. Microbiologyopen 2019, 8, e00840. [CrossRef] [PubMed]

65. Prosser, J.I.; Head, I.M.; Stein, L.Y. The family Nitrosomonadaceae. In The Prokaryotes: Alphaproteobacteria and Betaproteobacteria; Springer: Berlin/Heidelberg, Germany, 2014; Volume 9783642301, pp. 901-918, ISBN 9783642301971. 